\title{
Review and Prospect of Research on Urban Land Use Efficiency
}

\author{
Xuehao Bi \\ School of Geographical Mapping and Urban and Rural Planning, Jiangsu Normal University, \\ Jiangsu Xuzhou China \\ 1595968094@qq.com
}

Keywords: Land use efficiency; Influence factors; The scale of the city; Volume rate index

\begin{abstract}
Against the background of increasing land resources constraints, to improve the land use efficiency has become the key issue of China's urbanization. Based on the review of connotation, involved theories, constructing index system, influence factors, research methods of the land use efficiency, this paper summed up the vague concept, lack of timing research and the analysis of influence factors on land use efficiency. On the basis of the analysis of the shortage in the existing researches, much attention should be paid to the theoretical analysis, the effect researches of land use efficiency policy and detailed analysis of the scale of the city in the future.
\end{abstract}

\section{Introduction}

Land use is a series of biological and technological activities for economic and social purposes, namely a long-term or cyclical operation process. Land use is not only restricted by natural conditions, but also influenced by economic, technological and social conditions. Against the background of increasing land resources constraints, to improve the land use efficiency has become the key issue of China's urbanization. To study urban land use efficiency can promote the development of urban economy, scientifically judge the reasonable size and scope of the new construction land in the city and meet the normal needs of land resources, so as to reduce the blind expansion of urban land which may bring pressure on cultivated land. Urbanization construction has strong demand for land resources, meanwhile, limited land resources have seriously constrained their own supply capacity. Therefore, the increasingly acute contradiction between supply and demand has become a major bottleneck restricting the healthy development of the future economy. Furthermore, how to improve land use efficiency is an important research topic. This paper summarized the research results of domestic and foreign scholars, and we hope to further refine the methods and Countermeasures of land use in the process of national urbanization.

\section{Review on the Research of Urban Land Use Efficiency}

Definition of the Concept of Land Use Efficiency. Land use efficiency of the connotation for the construction was seldom defined, although some scholars from Britain, France and the United States, often use the building density and volume rate index to evaluate land use efficiency. Land use efficiency defined by the domestic scholars varies from person to person, such as, Ganghui Luo (2003), Yongle Li (2014) think that Land use efficiency is the industrial added value per unit area, what's more, urban land use efficiency is the added value of per built area in the second or third industry; Baode Bi (2011) believes that urban land use efficiency is the social, economic and ecological benefits produced by urban land, which reflects the targets of human use of land; Xiaobo Zhao (2013) argues that land use efficiency is that, when people take the land resources as the factors of production, they make full use of land resources and achieve the maximization of its output, by constantly improving production technology and rationally allocating proportion of production factors. Although the definition of land use efficiency differs, its essence includes two aspects: (1)under the condition that the output is fixed, the input is reduced as much as possible, or under the condition that the input element is fixed, the output is increased as much as possible.; (2) to allocate rationally the proportion of various factors of production is to achieve the optimal combination between the various factors of production 
Correlated Theory on Land Use Efficiency. Land rent theory is one of the important research fields in economics. It not only reveals the essence of the land price, but also reveals the difference between the land system and the property right system, which is further decomposed into classical economics theory of land rent, new classical economics theory of land rent, Marx's theory of land rent and Alonso bid rent theory.

The land location theory was originated in the study of differential rent, then gradually developed into a general theory of spatial economic activities, which includes agricultural location theory, industrial location theory, central land theory, market location theory. It is the theoretical basis of land allocation, that is, the layout of urban and rural residential spots and various industrial production land. Urban land zoning is a process of orderly and rational use of land according to the law of urban function zoning.

Urban land use structure theory is the study on the utilization of urban land location from the combined structure system of urban function areas, which is inevitable to encounter in the development of cities. In this sense, they have the reference value for the research of land use in China city.

Sustainable land use theory is a new concept of urban land use. Not only should the economic benefits of land allocation be considered, much attention also should be paid to the economic benefits, social benefits and environmental benefits of urban land allocation, in order to reach a fair and reasonable and efficient level.

Study on the Index System of Land Use Efficiency. There are researches on land use efficiency index. Researchers have constructed different index systems from varies angles. Common structural scales are shown in Table 1.

Table 1 index system of land use efficiency

\begin{tabular}{|c|c|}
\hline Dewen Wu & $\begin{array}{l}\text { Input indicators: urban construction land area, fixed assets investment, the second } \\
\text { and third industry practitioners; } \\
\text { Output indicators: added value of the second and third industries (economic } \\
\text { benefits); green area, urban construction and maintenance funds (environmental } \\
\text { benefits) }\end{array}$ \\
\hline $\begin{array}{l}\text { Ruizhong } \\
\text { Zheng }\end{array}$ & Urban population density, built-up area ratio, output of urban land \\
\hline $\begin{array}{l}\text { Qingkun } \\
\text { Wang }\end{array}$ & $\begin{array}{l}\text { Economic benefits: per capita GDP, the second and third industry added value, } \\
\text { retail sales of social goods and fiscal revenue in built-up areas, proportion of the } \\
\text { third industry added value accounted for GDP } \\
\text { Social benefits: public facilities land ratio in built-up areas, traffic land ratio, per } \\
\text { capita disposable income, registered urban public transport vehicles in per million } \\
\text { people, the employment rate in cities, the per capita city maintenance and } \\
\text { construction fund, population load in built-up areas } \\
\text { Environmental benefits: green coverage rate, per capita public green land, } \\
\text { wastewater discharge compliance rate, solid waste comprehensive utilization rate, } \\
\text { industrial dust treatment rate in built-up area }\end{array}$ \\
\hline $\begin{array}{l}\text { Changlan } \\
\text { Gong }\end{array}$ & $\begin{array}{l}\text { Land input indicators: the urban built-up area; capital investment index: fixed } \\
\text { assets investment, fiscal expenditure; labor input index: second industry } \\
\text { practitioners, third industry professionals; environmental input indicators: per } \\
\text { capita green area; economic benefit index: fiscal revenue, GDP, proportion of the } \\
\text { second industry and third industry; social life indicators: per capita disposable } \\
\text { income of urban residents }\end{array}$ \\
\hline $\begin{array}{l}\text { Juntao } \\
\text { Zhang }\end{array}$ & $\begin{array}{l}\text { Input indicators: urban built-up area, urban non-farm workers, urban fixed assets } \\
\text { investment; output indicators: urban non-farm output value, per capita total retail } \\
\text { sales of social goods, urban green space }\end{array}$ \\
\hline $\begin{array}{l}\text { Liangjian } \\
\text { Wang }\end{array}$ & $\begin{array}{l}\text { Population density, human capital, transportation infrastructure, information } \\
\text { level, public service facilities, foreign direct investment, fiscal expenditure, } \\
\text { financial scale, the degree of marketization of land, the type of urban construction } \\
\text { land }\end{array}$ \\
\hline
\end{tabular}

Study on the Influencing Factors of Land Use Efficiency. There are many factors influencing 
the efficiency of the land use, and the researchers have analyzed the influencing factors from different angles. Peter H Verburg (1999) thought that urbanization could change the used model and adjust the structure of land use in a wider range to improve the comprehensive efficiency of land use, from the perspective of land' market allocation. Xiaochuan Wang (2003) analyzed the impact of urban planning on urban land use efficiency, and put forward to the introduction of economic analysis and reasonable layout to improve the efficiency of land structure in the preparation of planning. Ruihua Xu (2004) pointed out that urban land resources allocation directly affects the function of urban economy and the efficiency of land use. Pu Zhou (2011) pointed out that the government's promotion and management system and industrial structure are the dominant factor affecting the land use efficiency by means of researches on the land use efficiency of Fengtai District in Beijing. Yong Yang (2011) pointed out that the location factor has not the same significant effect on the land use efficiency as the coastal areas, the level of land use efficiency depends on the density of material capital input, by analyzing the construction land efficiency of inland towns in Chongqing.

Research on the method of Land Use Efficiency. The research methods of land use efficiency include: coordination degree model, principal component analysis and weighted method, vague comprehensive evaluation method, regression analysis method, data envelopment analysis (DEA), system analysis and AHP etc.

\section{Review and Prospect of Research on Urban Land Use Efficiency}

Review. There are usually the following questions in the current study:

Vague concept of land use efficiency. The existing research about the concept of land use efficiency is not clearly defined. When the evaluation index and calculation method are selected at random, results of land use efficiency are greatly different. Therefore, the key problem of the study of land use efficiency is to make up for the defects of traditional indicators and accurately, comprehensively define the concept of land use efficiency.

Lack of timing research. The existing research in the use of data envelopment analysis (DEA) method mainly focus on the horizontal comparison between different regions, ignoring longitudinal dynamic fluctuation of land use. However, process of land use has the characteristics of continuity, dynamics and so on, so it is necessary to investigate the temporal characteristics of land use in order to realize the full disclosure and comparison of land use.

Lack of analysis of influencing factors of land use efficiency. The ultimate goal of calculating land use efficiency is to use land resources effectively and alleviate the supply of land resources to realize the sustainable development. Therefore, it is essential to analyze the influence factors of land use efficiency. Only systematic and comprehensive analysis of the impact factors of land use efficiency, can evaluation index reasonably and accurately be selected and scientific and reasonable evaluation index system and evaluation model be built. The existing researches on land use efficiency are slightly lack

Prospect. In the future, attention should be paid to the theoretical analysis. Firstly, through the derivation of the micro model, the most fundamental factors that affect the land use efficiency are found, so as to provide the corresponding theoretical basis for the empirical analysis of the influencing factors. Secondly, it is necessary to make a further study on the policy and effect of improving the efficiency of land resource utilization. Finally, in the urban land use factors, there is no specific analysis of the factors that affect the efficiency of land use, such as, urban scale, per capita land use control, volume ratio, etc. We need to further study how these indicators affect the efficiency of urban land use, how to determine the reasonable size of the city, the per capita land control indicators, volume ratio, and so on.

\section{Acknowledgements}

Jiangsu Normal University doctoral degree teacher's research support project (09XLR16); Jiangsu normal university student's innovation and entrepreneurship training program (XSJCX6005) 


\section{References}

[1] Anselin L. Spatial Eeonometrics: Methods and Models. Dordrecht: Kluwer Academic Publishers, 1988:101-109

[2] Barbier E.B. Endogenous Growth and Natural Resource Seareity. Environmental and Resource Economics, 1999(14): 51-74

[3] Barrett S.Economic Growth and Environment Preservation. Journal of Environmental Economics and Management, 1992(23):289-300

[4] Beekerman W.Economist, Seientist and Environmental Catastrophe. Oxford Economic papers, 1972(24):237-244

[5] Boger, B.D and K.Kerstens (1996), Cost Effciency of Belgium Local Goverments: AComparative Analrsis of FDH, DEA and Econometric Approaches, Regional Science and Urban Economics, Vol.26, pp.145-170

[6] Brown L.R, Hilweil B. China's Water Shortage Could Shake World Food Security. World Watch, 1998:10-18

[7] Xiaobo Zhao. Quantitative analysis of land use efficiency in China [D]. Liaoning University, 2013,12

[8] Ruizhong Zheng. Study on the efficiency of urban land use in China [D]. Dongbei University of Finance and Economics, 2014,12

[9] Qingkun Wang. Study on urban land use efficiency and its evaluation in the process of urbanization [D].2007,6

[10]Weidong Liu, Jun Peng. Land resource management [M]. Shanghai: Fudan University press, 2005.8

[11]Wanmao Wang. Land resource management [M]. Beijing: Higher Education Press, 2003.8 